Marcin Lysko

Uniwersytet w Białymstoku e-mail: marcin.lysko@uwb.edu.pl telefon: 504103803

DOI: $10.15290 /$ mhi.2017.16.01.10

\title{
System sankcji w prawie wykroczeń europejskich państw socjalistycznych
}

\author{
SUMMARY \\ The system of sanctions in the Misdemeanour Law \\ of European socialist countries
}

After the 2nd World War the Misdemeanour Law of European socialist countries included, apart from the traditional penalties, measures of an educational character. The assumption of gradual abolition of repressive measures accompanying the development of a socialist society lay in the basis for introducing them. Typically, a fine was the basic sanction for committing an offence. The highest upper limit of fine was provided for in the legislation of Hungary, Bulgaria and Poland. It was the Polish Misdemeanour Law which used the maximum allowable fine most often. Custodial detention was common in the Misdemeanour Laws of Yugoslavia as well as in Poland, which also used the alternative penalty of arrest and detention in cases of non-payment of a fine. In Hungary and the Soviet Union, the penalty of detention was of exceptional character. However, as its upper time limit of detention was three times higher than in other countries, the Polish Misdemeanour Law is to be perceived as being the most restrictive. The punishment of a three-months detention for every third misdemeanour committed, was provided for in the Misdemeanour Law codification of 1971 of the People's Poland.

Key words: Misdemeanour Law, the system of sanctions, socialism

Słowa kluczowe: prawo wkroczeń, system sankcji, socjalizm

Niniejszy artykuł porusza problematykę środków reakcji na fakt popełnienia wykroczenia przewidzianych w ustawodawstwie europejskich państw socjalistycznych, która zostanie przedstawiona w aspekcie prawnoporównawczym. Analiza prawnoporównawcza rozwiązań obowiązujących w okresie poprzedzającym skodyfikowanie w 1971 r. polskiego prawa wykroczeń ma na celu ustalenie stopnia jego represyjności na tle systemów prawa wykroczeń 
państw tzw. bloku wschodniego. Trzon materialnego prawa wykroczeń Polski Ludowej stanowił obowiązujący po dzień dzisiejszy kodeks wykroczeń ${ }^{1}$ (k.w.), który w założeniu jego twórców realizował koncepcję polaryzacji wykroczeń i rozwarstwienia odpowiedzialności ${ }^{2}$. W myśl tej koncepcji surowa represja karna miała ograniczać się do przypadków, gdy czyn cechował wysoki stopień szkodliwości społecznej, a jego popełnieniu towarzyszyły zła wola i demoralizacja sprawcy. Natomiast względem sprawców wykroczeń o mniejszym ciężarze gatunkowym przewidziano łagodzenie represji, a nawet odstąpienia od niej na rzecz zastosowania pozakarnych środków wychowawczych ${ }^{3}$.

Surowe kary miały być stosowane przede wszystkim wobec sprawców wykroczeń powstałych z przekształcenia dotychczasowych występków, gdyż k.w. pogłębiał zapoczątkowany tzw. ustawą o przekazaniu ${ }^{4} \mathrm{z}$ dnia 17 czerwca 1966 r. proces kontrawencjonalizacji ${ }^{5}$. Zgrupowane w części szczególnej kodeksu liczne wykroczenia „przekazane” były zagrożone karą aresztu zasadniczego w wymiarze od tygodnia do 3 miesięcy. Ta najsurowsza $\mathrm{z}$ kar zasadniczych była także stosowania wobec sprawców wykroczeń o charakterze administracyjnym, zwłaszcza dopuszczających się poważniejszych, zdaniem ustawodawcy, naruszeń porządku i spokoju publicznego oraz wykroczeń narażenia na niebezpieczeństwo. Wprawdzie k.w. zawierał deklarację podkreślającą wyjątkowy charakter kary aresztu oraz $\mathrm{w}$ sposób precyzyjny formułował przesłanki leżące u podstaw stosowania tej kary ${ }^{6}$, lecz występowała ona w sankcjach 42 artykułów części szczególnej kodeksu. Wynika z tego, iż co trzecie zgrupowane w kodeksie wykroczenie było zagrożone aresztem, który występował także w sankcjach 19 typów wykroczeń uregulowanych w ustawach szczególnych ${ }^{7}$. Celem stworzenia podstaw dla prowadzenia elastycznej polityki karnej wobec sprawców wykroczeń o dużym ciężarze gatunkowym recypowano z kodeksu karnego ${ }^{8}$ karę ograniczenia wolności. Wymierzana na okres od 1 do 3 miesięcy kara ograniczenia wolności polegała na wykonywaniu pod nadzorem nieodpłatnej pracy na cele społeczne $\mathrm{w}$ wymiarze od 20 do 50 godzin.

1 Ustawa z dnia 20 maja 1971 r. - Kodeks wykroczeń (Dz. U. Nr 12, poz. 114).

2 Projekt prawa o wykroczeniach. Uzasadnienie, Warszawa 1970, s. 65.

3 A. Marek, Problemy reformy polskiego prawa wykroczeń, w: Problemy odpowiedzialności karnej. Księga pamiątkowa ku czci Profesora Kazimierza Buchały, red. Z. Ćwiąkalski, Kraków 1994, s. 197.

4 Ustawa z dnia 17 czerwca 1966 r. o przekazaniu niektórych drobnych przestępstw jako wykroczeń do orzecznictwa karno-administracyjnego (Dz. U. Nr 23, poz. 149).

5 Termin wprowadzony przez I. Andrejewa, Ustawowe znamiona czynu. Typizacja i kwalifikacja przestępstw, Warszawa 1978, s. 62.

6 Na znaczenie tego rozwiązania wskazywał m.in. A. Gubiński, Wokót problemów nowej kodyfikacji, "Zagadnienia Wykroczeń" (dalej: ZW) 1972, nr 2, s. 8.

7 W. Radecki, System kar i innych środków oddziaływania w prawie wykroczeń, „Służba MO” 1977, nr 4-5, s. 500 .

8 Ustawa z dnia 19 kwietnia 1969 r. - Kodeks karny (Dz. U. Nr 13, poz. 94). 
Jednakże cechujące tą karę założenie wychowawczego oddziaływania przez pracę społecznie użyteczną praktycznie nie występowało $\mathrm{w}$ przypadku pracowników uspołecznionych zakładów pracy. Wobec tej kategorii sprawców wykroczeń przewidziano stosowanie alternatywnej formy kary ograniczenia wolności w postaci potrącenia od 10 do $25 \%$ wynagrodzenia na rzecz Skarbu Państwa lub na inny cel społeczny9.

Dominującą pozycję w katalogu kar zasadniczych kodyfikacji z 1971 r. posiadała grzywna, gdyż poza jednym wyjątkiem ${ }^{10}$ była przewidziana $w$ sankcji wszystkich przepisów części szczególnej k.w. Jako podstawowy środek represji ekonomicznej grzywny była orzekana w wymiarze od 100 do 5000 złotych, przy czym sankcje przeważającej części wykroczeń ujętych w kodeksie przewidywały maksymalny pułap tej kary. Co do zasady, grzywna przybierała postać kary orzekanej samoistnie, jedynie $\mathrm{w}$ przypadku popełnienia wykroczenia z chęci zysku przewidziano jej orzekanie łącznie z karą aresztu zasadniczego ${ }^{11}$. W przypadku grzywien powyżej 1000 złotych k.w. dopuszczał orzeczenie aresztu zastępczego na wypadek nieuiszczenia grzywny przez osobę ukaraną. Katalog kar zasadniczych uzupełniała kara nagany, którą charakteryzowało wyłącznie oddziaływanie moralne wobec sprawcy wykroczenia o niewielkim ciężarze gatunkowym ${ }^{12}$.

Oprócz kar zasadniczych k.w. zawierał katalog kar dodatkowych, które uzupełniały dolegliwość wynikającą z orzeczenia kary zasadniczej. U podstaw wprowadzenia większości tych kar legło założenie oddziaływania profilaktycznego i zabezpieczającego, na co wskazuje dopuszczalność samoistnego ich stosowania w przypadku odstąpienia od wymierzenia kary zasadniczej. Największa dolegliwość cechowała kary dodatkowe zakazu prowadzenia określonej działalności lub wykonywania czynności związanych z wymaganym zezwoleniem oraz zakazu prowadzenia pojazdów mechanicznych. Pierwsza nich mogła być orzeczona na okres od 3 miesięcy do roku, podczas gdy zakaz prowadzenia pojazdów mechanicznych nawet na dwa lata. Katalog kar dodatkowych uzupełniały przepadek rzeczy oraz podanie orzeczenia o ukaraniu do publicznej wiadomości. Przepadek rzeczy obejmował przedmioty służące do popełnienia wykroczenia oraz na podstawie przepisów szczególnych także przedmioty pochodzących z wykroczenia. Natomiast podanie orzeczenia o ukaraniu do publicznej wiadomości miało miejsce wtedy, gdy zdaniem organu orzekającego przemawiały za tym względy wychowawcze. O ile stosowanie tej kary dodat-

9 J. Bafia, Kodyfikacja prawa o wykroczeniach, „Państwo i Prawo” (dalej: PiP) 1971, nr 10, s. 516.

10 Chodziło o przewidziane w art. $58 \S 2$ k.w. wykroczenie żebrania w sposób natarczywy lub oszukańczy. Groziły za nie kary aresztu lub ograniczenia wolności w maksymalnym wymiarze.

11 B. Adamiak, Ewolucja systemu kar w orzecznictwie w sprawie wykroczeń w PRL, „Acta Universitatis Wratislaviensis. Przegląd Prawa i Administracji" 1976, t. VIII, s. 115.

12 Cz. Bareja, Nowe prawo o wykroczeniach, „Przegląd Pożarniczy” 1971, nr 9, s. 7. 
kowej ustawodawca pozostawił swobodnemu uznaniu organu orzekającego, o tyle pozostałe kary mogły być orzekane - obligatoryjnie lub fakultatywnie wyłącznie na podstawie upoważnień zawartych w przepisach szczególnych ${ }^{13}$.

Kodyfikacja z 1971 r. przewidywała możliwość stosowania wobec sprawców wykroczeń środków o charakterze nierepresyjnym w przypadku odstąpienia od wymierzenia kary lub rezygnacji z wszczęcia postępowania lub przez organy ścigania. W pierwszej $z$ omawianych sytuacji miały zastosowanie środki oddziaływania społecznego, których celem było przywrócenie naruszonego porządku prawnego lub naprawienie wyrządzonej szkody. Z kolei środki oddziaływania wychowawczego służyły wdrożeniu sprawy do poszanowania prawa i przestrzegania zasad współżycia społecznego. W ramach tej instytucji dopuszczalne było zarówno zwrócenie sprawcy uwagi, jak też zastosowanie wobec niego środków przewidzianych w regulaminach pracy, w postępowaniu dyscyplinarnym lub postępowaniu przed sądami społecznymi ${ }^{14}$. Fakt szerokiego uwzględnienia przez twórców k.w. instytucji środków oddziaływania wychowawczego postrzegano jako nawiązanie do tendencji występującej w pozostałych europejskich krajach socjalistycznych ${ }^{15}$. Kolejne podobieństwo wyrażało się w skodyfikowaniu prawa wykroczeń Polski Ludowej w niedługim czasie po uchwaleniu stosownych ustaw regulujących kompleksowo problematyke wykroczeń w większości państw bloku wschodniego. W 1968 r. ustawy o wykroczeniach przyjęto w Niemieckiej Republice Demokratycznej (NRD), na Węgrzech i w Rumunii, a w 1969 r. dokonała tego Bułgaria ${ }^{16}$.

Jako pierwsza problematykę wykroczeń uregulowała NRD w pochodzącej z 12 stycznia 1968 r. ustawie o zwalczaniu wykroczeń porządkowych, która stanowiła jeden z aktów składających się na kompleksową kodyfikację prawa karnego ${ }^{17}$. Wykroczenia porządkowe postrzegano jako czyny niegodzące $\mathrm{w}$ sposób istotny $\mathrm{w}$ interesy społeczeństwa socjalistycznego i poszczególnych obywateli ${ }^{18}$. Wobec sprawców tej kategorii wykroczeń przewidziano stosowanie trzech środków karnoporządkowych, które według polskiej terminologii przybierały postać kar zasadniczych. Były to nagana, grzywna w wysokości do 300

13 J. Jendrośka, Rozwój orzecznictwa w sprawach o wykroczenia w Polsce, „Acta Universitatis Wratislaviensis. Przegląd Prawa i Administracji" 1978, t. X, s. 95-96.

14 A. Gubiński, Środki oddziaływania wychowawczego na tle zasady celowości w prawie wykroczeń, PiP 1972, nr 10, s. 32-33.

15 K. Jandy-Jendrośka, J. Jendrośka, Instytucje postępowania w sprawach wykroczeń administracyjnych, [w:] Instytucje prawa administracyjnego europejskich państw socjalistycznych, red. J. Starościak, Warszawa 1973, s. 447.

16 J. Skupiński, Model polskiego prawa o wykroczeniach, Wrocław - Warszawa - Kraków - Gdańsk 1974, s. $181-182$.

17 E. Buchholz, Nowe prawo karne NRD, „Przegląd Penitencjarny” 1968, nr 3, s. 48.

18 M. Łysko, Prawo wykroczeń Niemieckiej Republiki Demokratycznej, „Miscellanea Historico-Iuridica” 2009 , t. VII, s. 127. 
lub 500 marek oraz upomnienie połączone z tzw. wpłatą porządkową ${ }^{19}$. Bardziej obszerny był katalog dodatkowych środków karnoporządkowych, które wbrew przyjętej przez ustawodawcę terminologii mogły być również stosowane samoistnie. Spośród nich występowały nieznane polskiemu prawu wykroczeń wpis do akt pracowniczych zawierający adnotację o naruszeniu obowiązków prawych oraz powołanie do wykonywania pracy powszechnie użytecznej w czasie wolnym od pracy ${ }^{20}$.

Również w pierwszej połowie 1968 r. kodyfikacji prawa wykroczeń dokonała Węgierska Republika Ludowa. Podstawowym aktem regulującym problematykę wykroczeń była ogłoszona 14 kwietnia 1968 r. ustawa nr I, aczkolwiek nie obejmowała ona całej części szczególnej prawa materialnego. Stany faktyczne pozostałych wykroczeń zawierało wydane tego samego dnia rozporządzenie Rządu nr 17, które wraz z ustawą nr I składało się na kompleksową kodyfikację prawa wykroczeń Węgierskiej Republiki Ludowej ${ }^{21}$. Oprócz tradycyjnych wykroczeń godzących w działalność aparatu administracji państwowej, węgierskie prawo wykroczeń zawierało czyny o charakterze kryminalnym, posiadające swoje odpowiedniki w kodeksie karnym. Były one kwalifikowane jako wykroczenia $\mathrm{w}$ wyniku zastosowania ustawowego kryterium ocennego wypadku małej wagi. Charakter wykroczenia nie posiadał zasadniczego znaczenia przy ustanawianiu sankcji, gdyż przewidziane w ustawie nr I kary zasadnicze aresztu oraz grzywny były przewidziane wobec sprawców obydwu kategorii wykroczeń. Posiadająca wyjątkowy charakter kara aresztu w wymiarze od 1 do 30 dni groziła zawsze alternatywnie z grzywną sprawcom siedmiu najpoważniejszych, zdaniem węgierskiego ustawodawcy, wykroczeń ${ }^{22}$.

Podstawową karą grożącą sprawcom wykroczeń była grzywna w wysokości od 20 do 5000 forintów, która w razie nieuiszczenia i braku możliwości ściągnięcia jej $\mathrm{w}$ drodze egzekucji podlegała zamianie na areszt zastępczy. Podobnie jak w przypadku kary zasadniczej, wymiar aresztu orzeczonego w zamian za nieuiszczoną grzywnę nie mógł przekroczyć 30 dni. Oprócz kar aresztu i grzywny węgierski system materialnego prawa wykroczeń przewidywał inne środki w postaci upomnienia, konfiskaty oraz opublikowania orze-

19 J. Skupiński, Prawo o wykroczeniach w europejskich państwach socjalistycznych, t. 2, Niemiecka Republika Demokratyczna, Wrocław - Warszawa - Kraków - Gdańsk 1977, s. 17.

20 Ordnungswidrigkeitrecht der DDR. Kommentar zum Ordnungswidrigkeitsgesetz und zur Ordnungswidirgkeitsverordnung, Berlin 1989, s. 32-35.

21 Z. Haczewski, Węgierskie prawo o wykroczeniach, „Gazeta Sądowa i Penitencjarna” 1969, nr 13, s. 8-9.

22 Spośród nich charakter kryminalny posiadały pasożytnictwo, prostytucja, chuligaństwo, bójka oraz groźba. Do grupy wykroczeń o administracyjnym rodowodzie zaliczano naruszenie zakazu przebywania w określonym miejscu lub postanowień dotyczących nadzoru milicyjnego oraz uchylanie się od kuracji odwykowej. J. Skupiński, Prawo o wykroczeniach w europejskich państwach socjalistycznych, t. 1, Ludowa Republika Bułgarii, Węgierska Republika Ludowa, Wrocław - Warszawa - Kraków Gdańsk 1975, s. 79. 
czenia. Środki te były orzekane zamiast lub obok kary, przy czym każdy z nich posiadał specyficzny charakter ${ }^{23}$. Upomnienie stanowiło środek oddziaływania wychowawczego, gdyż jego orzeczenie $w$ miejsce kary miało przynieść należyty skutek wychowawczy względem sprawcy. Jako karę dodatkową należy postrzegać konfiskatę przedmiotów służących do popełnienia wykroczenia lub uzyskanych z wykroczenia, która była orzekana obligatoryjnie lub fakultatywnie w przypadkach wskazanych w części szczególnej. Konfiskaty można było dokonać także wtedy, gdy sprawcy nie można było przypisać odpowiedzialności za wkroczenie lub jego pociągnięcie do odpowiedzialności wykluczały przepisy procesowe. Charakter kary dodatkowej posiadało także podanie prawomocnego orzeczenia o ukaraniu aresztem lub grzywną do publicznej wiadomości. Środek ten miał być stosowany w sytuacji, gdy zdaniem organu orzekającego przyczyni się do zwiększenia wychowawczego i zapobiegawczego wpływu orzeczenia na sprawcę wykroczenia ${ }^{24}$.

Jako ostatnia w 1968 r. ustawę regulującą problematykę wykroczeń wydała Rumunia, która dokonała tego $\mathrm{w}$ ramach prac nad kompleksową kodyfikacją prawa karnego. Ustawa z dnia 12 listopada 1968 r. o ustalaniu i karaniu wykroczeń określała sankcje grożące sprawcom wykroczeń mianem kar administracyjnych. Posunięcie to służyło podkreśleniu odmienności kar orzekanych za wykroczenia od kar wymierzanych sprawcom przestępstw w trybie postępowania karnego. Katalog kar administracyjnych był dosyć skromny, gdyż składał się z grzywny oraz upomnienia. Charakter kary dodatkowej posiadała przewidziana $\mathrm{w}$ przepisach szczególnych konfiskata przedmiotów. Podstawową karą grożącą sprawcom wykroczeń była grzywna, której maksymalną wysokość określono zasadniczo na 1500 lei. Jedynie w wyjątkowych przypadkach podyktowanych szczególnym charakterem czynu, takich jak recydywa, wykroczenia popełnione $\mathrm{z}$ chęci zysku lub z pobudek antyspołecznych, dopuszczalne było ustanowienie górnego pułapu grzywny na poziomie $3000 \mathrm{lei}^{25}$. Kolejna z kar administracyjnych - upomnienie - miała być stosowana w miejsce grzywny w przypadkach małej wagi, przy czym ustawa wyraźnie podkreślała wychowawczy cel tej kary. Występująca w przepisach szczególnych konfiskata dotyczyła przedmiotów służących do popełnienia wykroczenia, uzyskanych $\mathrm{w}$ jego następstwie oraz uzyskanych $\mathrm{z}$ racji popełnienia wykroczenia. Ponadto, ustawa z 12 listopada 1968 r. przewidywała obligatoryjny przepadek przedmiotów, których przechowywanie lub rozpowszechnienie było zabronione ${ }^{26}$. s. 112

24 bezpieczne, „Prace Naukowe Uniwersytetu Śląskiego. Problemy Prawa Karnego” 1988, nr 14, s. $118-119$. 
Pod koniec lat sześćdziesiątych ustawę regulującą problematykę wykroczeń przyjęła także Bułgaria, aczkolwiek uchwaloną 20 listopada 1969 r. ustawę o wykroczeniach i karach administracyjnych trudno określić mianem kompleksowej regulacji. Wspomniana ustawa zawierała jedynie przepisy regulujące zasady odpowiedzialności oraz kary grożące sprawcom wykroczeń, czyli najważniejsze zagadnienia składające się na część ogólną prawa materialnego. W pozostałych kwestiach części ogólnej ustawa z 20 listopada 1969 r. przewidywała odpowiednie stosowanie wydanego półtora roku wcześniej kodeksu karnego ${ }^{27}$. Wzorem bułgarskiego kodeksu karnego regulacje ustawy z 20 listopada 1969 r. dotyczące środków stosowanych wobec sprawców wykroczeń nie wprowadzały podziału na kary zasadnicze i dodatkowe. Ustawa przewidywała jedynie trzy kary, spośród których podstawową rolę odgrywała grzywna. Maksymalna wysokość kary grzywny wynosiła 300 lewa, jedynie w przypadku ponownego popełnienia wykroczenia administracyjnego dopuszczalne było orzeczenie tej kary w wysokości do 500 lewa. Kolejne miejsce w katalogu kar zajmowała nagana społeczna, która na gruncie bułgarskiego prawa karnego i prawa wykroczeń przybierał postać środka karnego, a nie środka wychowawczego. Ostatnią z kar grożącą sprawcom wykroczeń było czasowe pozbawienie uprawień do wykonywania zawodu lub prowadzenia określonej działalności ${ }^{28}$. System materialnego prawa wykroczeń zawierał również środki nieokreślane przez ustawę z 20 listopada 1969 r. mianem kar, którymi były przepadek przedmiotów oraz nałożenie obowiązku odszkodowawczego. Przewidywał instytucję odstąpienia od wymierzenia kary połączoną z zastosowaniem środków o charakterze wychowawczym. W przypadku małej wagi wykroczenia organ orzekający mógł zamiast kary udzielić sprawcy pisemnego lub ustnego ostrzeżenia, lub też przekazać sprawę do rozpatrzenia przez sąd społeczny ${ }^{29}$.

Znacznie wcześniej niż to miało miejsce w Polsce, bo na początku lat sześćdziesiątych zasadniczą reformę systemu prawa wykroczeń przeprowadzono w Czechosłowacji. Uchwalona 24 czerwca 1961 r. ustawa "o zadaniach rad narodowych $\mathrm{w}$ dziedzinie zabezpieczenia socjalistycznego porządku prawnego" miała przyczynić się do stopniowego wyeliminowania z systemu prawa karno-administracyjnego elementów karnych i zastępowania ich systemem środków wychowawczych. Podstawowym celem postępowania w sprawach o wykroczenia było osiągniecie określonego efektu wychowawczego, w pierwszej kolejności za pomocą metod przekonywania i pozakarnego odziaływania na sprawcę

27 K. Jandy-Jendrośka, J. Jendrośka, op. cit., s. 433.

28 J. Skupiński, Bułgarskie prawo wykroczeń, ZW 1973, nr 6, s. 60-61.

29 Idem, Prawo o wykroczeniach..., t. 1, s. 14. 
wykroczenia ${ }^{30}$. Dopiero w sytuacji, gdy metody te nie przyniosły efektu w postaci świadomego przestrzegania przez obywateli prawa oraz dobrowolnego wykonywania obowiązków wobec państwa, przewidziano stosowanie uregulowanych we wspomnianej ustawie środków ${ }^{31}$. Dążąc do podkreślenia ich wychowawczego charakteru czechosłowacki ustawodawca świadomie zrezygnował z określenia kara (tresta), które odnosiło się wyłącznie do sankcji grożących za przestępstwa. Stosowane wobec sprawców wykroczeń środki nosiły nazwę opatreni ${ }^{32}$. Były nimi upomnienie, nagana publiczna oraz grzywna w wysokości do 500 koron, której nawet w przypadku nieściągalności nie można było zamienić na areszt. Charakter środka dodatkowego posiadał przepadek przedmiotów użytych do popełnienia wykroczenia lub uzyskanych z wykroczenia. Ponadto, na sprawcę wykroczenia, któremu wyrządzono szkodę $\mathrm{w}$ mieniu można było nałożyć obowiązek odszkodowawczy ${ }^{33}$.

Jako pierwsza spośród europejskich krajów socjalistycznych kompleksowej kodyfikacji prawa wykroczeń dokonała Jugosławia. Uchwalona w $1951 \mathrm{r}$. ustawa o wykroczeniach definiowała wykroczenie jako „określone ustawą lub innym przepisem naruszenie porządku publicznego, za które grożą kary za wykroczenia i środki ochronne". Z definicji tej wynika, iż środki orzekane wobec sprawców wykroczeń dzieliły się na kary i środki ochronne. Katalog kar zasadniczych tworzyły grzywna oraz kara pozbawienia wolności. Wysokość kary grzywny zamykała się w granicach 5 do 500 dinarów, aczkolwiek 20-krotnie wyższy górny pułap przewidywały przepisy regulujące odpowiedzialność za wykroczenia celne, dewizowe i podatkowe. Kara pozbawienia wolności mogła być orzekana w wymiarze od 1 do 30 dni wobec osób fizycznych ponoszących odpowiedzialność za inne wykroczenia niż gospodarze $^{34}$. Znacznie szerszy był katalog orzekanych wyłącznie obok kary środków ochronnych, których podstawą stosowania były przepisy ustaw szczególnych typizujących poszczególne stany faktyczne wykroczeń. Były to: pozbawienie przedmiotu służącego do popełnienia lub uzyskanego za pomocą wykroczenia, pozbawienie osiągniętych $\mathrm{w}$ wyniku popełnienia wykroczenia korzyści majątkowych, pozbawienie prawa wykonywania określonego zajęcia lub działalności, pozbawienie prawa posiadania i noszenia broni, wydalenie cudzoziemca $\mathrm{z}$ terytorium Jugosławii na okres do 2 lat oraz nałożenie obowiązku leczenia przeciwalkoholowego. Nowelą z 1965 r. zniesiono środek ochronny w postaci wysiedlenia, zaś dwa lata później z katalogu środków

\footnotetext{
30 P. Levit, Sprava a sprawvni prawo. Obecna cast, Praha 1964, s. 239.

31 Z. Cerveny, Spravni trestani, [w:] Z. Lukes a kolektiv, Ceskoslovenske spravni pravo, Praha 1981, s. 188.

32 W. F. Dąbrowski, Zagadnienia ogólne orzecznictwa karno-administracyjnego w PRL, Poznań 1970, s. 37

33 Idem, Orzecznictwo w sprawach wykroczeń w Czechosłowackiej Republice Socjalistycznej, „Zagadnienia Karno-Administracyjne" (dalej: ZKA) 1964, nr 6, s. 53

34 S. Popovic, Upravno pravo. Opsti deo, Belgrad 1965, s. 292-293.
} 
ochronnych usunięto skierowanie $\mathrm{w}$ celu przebywania $\mathrm{w}$ określonym miejscu na okres do 2 lat $^{35}$.

Jugosłowiański ustawodawca dopuszczał możliwość wyjątkowego stosowania zamiast kary grzywny lub pozbawienia wolności środków o charakterze wychowawczym, takich jak nagana oraz umorzenie postępowania. Przesłanką orzeczenia nagany było „znikome znaczenie” wykroczenia oraz wystąpienie okoliczności „W znacznej mierze umniejszających odpowiedzialność sprawcy”. Ponadto, musiała wystąpić pozytywna przesłanka dotycząca zachowania się sprawcy, który w ocenie organu orzekającego nie popełni w przyszłości wykroczenia. W przypadku dodatniej prognozy istniała także możliwość umorzenia postępowania. Jednakże instytucja ta miała zastosowanie jedynie wobec sprawcy wykroczenia polegającego na niewykonaniu obowiązków nałożonych prawem lub wyrządzeniu szkody. Warunkiem umorzenia było wcześniejsze wypełnienie obowiązku lub wyrównanie szkody przed wydaniem orzeczenia $^{36}$.

Jedynym z krajów bloku socjalistycznego, w którym na początku lat siedemdziesiątych nie obowiązywała żadna ustawa kompleksowo regulująca problematykę prawa wykroczeń był Związek Radziecki. Wydawanie przepisów zawierających stany faktyczne poszczególnych wykroczeń oraz grożące za nie sankcje należało nie tylko do właściwości organów administracji ogólnozwiązkowej, republikańskiej oraz republik autonomicznych, lecz także terenowych organów władzy państwowej - rad delegatów ludu pracującego. Z myślą o ograniczeniu kręgu podmiotów uprawnionych do stanowienia przepisów z dziedziny prawa karnoadministracyjnego 21 lipca 1961 r. Prezydium Rady Najwyższej ZSRR wydało stosowny dekret, w którym ponadto uregulowano niektóre podstawowe instytucje prawa materialnego. Kolejny dekret $\mathrm{z}$ dnia 30 marca 1962 r. dążył do ujednolicenia struktury i zasad funkcjonowania rozpatrujących sprawy o wykroczenia komisji administracyjnych przy terenowych radach delegatów ludu pracującego oraz określenia zasad postępowania przez tymi komisjami ${ }^{37}$. Z zagadnień prawa materialnego dekret poruszył problematykę środków karnych stosownych wobec sprawców wykroczeń, spośród których podstawową rolę odgrywać miała kara grzywny. Wysokość kar grzywny została ujednolicona przez pierwszy z omawianych dekretów, u podstaw wydania którego legło założenie dalszego ograniczenia stosowania tego najważniejszego środka karnego. Odstąpiono od wymierzania grzywny w stosunku do osób prawnych z uwagi na fakt, iż dotychczasowy stan prawny prowadził do faktycznej bezkarności sprawców naruszeń, czyli funkcjonariu-

35 M. Vuckovic, A. Popovic, D. Lisica, Osnovni zakon o prekrsajima sa komentarom i posebnim saveznim proposima o prekrsajima, Belgrad 1967, s. 689.

36 J. Skupiński, Ustawodawstwo karno-administracyjne w Jugostawii, PiP 1970, nr 7, s. 87-89.

37 J. Starościak, Prawo karno-administracyjne w Zwiazku Radzieckim, ZKA 1964, nr 1, s. 62-63. 
szy tych jednostek. Znacznemu zmniejszeniu uległa górna wysokość grzywien orzekanych wobec sprawców wykroczeń, która w przypadku obywateli wynosiła 10 rubli, a funkcjonariuszy jednostek państwowych 50 rubli. Ustanowienie wyższych górnych pułapów kary grzywny dopuszczono jedynie w związku z potrzebą wzmożenia odpowiedzialności za pewne rodzaje wykroczeń na podstawie ustaw ogólnozwiązkowych lub republikańskich ${ }^{38}$. Zrezygnowano z przewidzianej $\mathrm{w}$ dotychczasowych regulacjach możliwości zamiany nieuiszczonej grzywny na karę pracy poprawczej, krytycznie oceniając dotychczasową praktykę stosowania tego środka. Założenie dalszego ograniczenia stosowania grzywny skutkowało wprowadzeniem przez dekret z 1961 r. możliwości orzeczenia $\mathrm{w}$ jej miejsce środka o charakterze wychowawczym, jakim było uprzedzenie. Ustawodawca nie wprowadził żadnych dyrektyw w kwestii stosowania uprzedzenia, pozostawiając ocenę całkowitej swobodzie organu orzekającego. Pochodzący z 1962 r. dekret rozszerzał katalog środków orzekanych przez komisje administracyjne o utratę prawa wykonywania zawodu lub określonej działalności oraz konfiskatę przedmiotu stanowiącego narzędzie wykroczenia lub pochodzącego $\mathrm{z}$ wykroczenia. $\mathrm{W}$ zależności od uznania organu orzekającego mogły być one stosowane zarówno w charakterze kar samoistnych, jak też dodatkowych. Ustawodawstwo niektórych republik rozszerzało katalog środków stosowanych wobec sprawców wykroczeń o naganę społeczną ${ }^{39}$.

Wyjątkowy charakter posiadały kary przewidziane za wykroczenia, które na mocy dekretów republikańskich były rozpatrywane przez orzekających jednoosobowo sędziów ludowych. W szczególnym trybie administracyjnym sędziowie ludowi rozstrzygali sprawy o drobne chuligaństwo, pasożytnictwo, drobną spekulację oraz złośliwe niewykonanie zalecenia milicjanta lub członka drużyny ludowej. Wobec sprawców tego rodzaju wykroczeń, obok grzywny, stosowano kary aresztu do 15 dni, pracy poprawczej w wymiarze do 2 miesięcy, a w przypadku osób dopuszczających się pasożytnictwa społecznego wysiedlenie do wyznaczonych miejscowości na czas od 2 do 5 lat ${ }^{40}$.

Przegląd rozwiązań obowiązujących $\mathrm{w}$ europejskich państwach socjalistycznych prowadzi do wniosku o występowaniu nie tylko szeregu podobieństw, lecz także istotnych różnic $\mathrm{w}$ zakresie sankcji grożących sprawcom wykroczeń. Spośród cech wspólnych na pierwszym miejscu należy wskazać fakt występowania w katalogu kar grzywny, która w praktyce orzecznictwa każdego $\mathrm{z}$ tych państw zajmowała dominującą pozycję ${ }^{41}$. Według poczynio-

38 A. Gubiński, Radzieckie ustawodawstwo karno-administracyjne, ZKA 1965, nr 1, s. 45.

39 W. I. Popowa, Podstawowe problemy ustawodawstwa o odpowiedzialności administracyjnej $w$ ZSRR, ZKA 1966, nr 3-4, s. 59-60.

41 A. Gubiński, Niektóre zagadnienia dotyczace ujęcia odpowiedzialności za wykroczenia w europejskich państwach socjalistycznych, ZW 1988, nr 1, s. 7. 
nych przez J. Skupińskiego w 1973 r. ustaleń zbliżona do polskiego pułapu górna granica kary grzywny występowała jako reguła na Węgrzech i w Bułgarii ${ }^{42}$, podczas gdy w NRD i Rumunii tylko w szczególnych przypadkach (np. recydywa, wykroczenie umyślne popełnione $\mathrm{z}$ chęci zysku lub antyspołecznych pobudek). Zasadniczo maksymalna górna granica grzywny wymierzanej w tych dwóch krajach została ustalona na poziomie zdecydowanie niższym niż w polskiej kodyfikacji materialnego prawa wykroczeń. Najniższą karę grzywny przewidywało ustawodawstwo radzieckie, zwłaszcza w przypadku grzywien wymierzanych osobom fizycznym. O ile w Polsce sprawca wykroczenia musiał liczyć się z możliwością ukarania grzywną w wysokości do 5000 złotych, to za naszą wschodnią granicą orzekano grzywny w kwocie nie wyższej niż 50 rubli, czyli 765 złotych $^{43}$. Inne niż grzywna środki o charakterze typowo represyjnym występowały jedynie w poszczególnych państwach bloku wschodniego. Większość z tych państw dążyła bowiem do rozbudowy systemu środków o charakterze wychowawczym kosztem ograniczenia roli środków represyjnych, zwłaszcza kary pozbawienia wolności ${ }^{44}$. W charakterze kary zasadniczej pozbawienie wolności było przewidziane $\mathrm{w}$ ustawodawstwie czterech państwach, spośród których zdecydowanie prym wiodła Polska. Polskie materialne prawo wykroczeń przewidywało zagrożenie aresztem zasadniczym szeregu wykroczeń zgrupowanych w części szczególnej kodyfikacji z $1971 \mathrm{r}$. oraz ujętych w niektórych ustawach pozakodeksowych. Wyjątkowy charakter kara aresztu posiadała w Związku Radzieckim, gdyż była orzekana zaledwie $\mathrm{w}$ kilku przypadkach uregulowanych $\mathrm{w}$ ustawach szczególnych. Podobnie było na Węgrzech, gdzie traktowana przez ustawodawcę w sposób wyjątkowy kara aresztu występowała jedynie w sankcjach 7 najpoważniejszych wykroczeń ${ }^{45}$. W nieco szerszym zakresie karą aresztu zasadniczego operowało jedynie prawo jugosłowiańskie, aczkolwiek nie wszystkie rodzaje wykroczeń mogły być zagrożone tą najsurowszą z kar zasadniczych. Zdecydowanie najwyższą górną granicę kary aresztu przewidywało polskie prawo wykroczeń, ustanawiając ją na poziomie 3 miesięcy. Dla porównania, w Jugosławii i na Węgrzech maksymalny pułap tej kary wynosił 1 miesiąc, podczas gdy w ZSRR jedynie 15 dni. Radziecki system prawa wykroczeń nie

42 W przypadku recydywy ustawodawstwo bułgarskie dopuszczało możliwość orzekania grzywny w wysokości dwukrotnie wyższej niż w Polsce. J. Skupiński, Prawo dotyczace wykroczeń w europejskich państwach socjalistycznych, „Problemy Praworządności” 1973, nr 11, s. 12-13.

43 Jako podstawę do porównania wysokości zagrożeń karą grzywny w Polsce na tle innych państw członkowskich Rady Wzajemnej Pomocy Gospodarczej J. Skupiński przyjął ogłoszony 14 marca 1973 r. przez Prezesa NBP tzw. średni kurs podstawowy z dopłatą. Jego zdaniem kurs ten najbardziej odpowiadał realnej wartości nabywczej walut zagranicznych w stosunku do złotego. J. Skupiński, Prawo dotyczace..., s. 12. 
operował zastępczą karą aresztu, która była znana jedynie ustawodawstwu Polski, Jugosławii i Węgier.

Specyficzny charakter polskiego systemu materialnego prawa wykroczeń podkreślała szeroko występująca w kodyfikacji z 1971 r. kara ograniczenia wolności, która zasadniczo nie była znana ustawodawstwu pozostałych europejskich państw socjalistycznych. Jako jej odpowiednik można potraktować radziecką karę pracy poprawczej, lecz była ona przewidziana zaledwie w kilku przepisach. W opinii A. Gubińskiego przeciwko powszechnemu wprowadzaniu tej kary w krajach bloku wschodniego przemawiał wzgląd na niecelowość orzekania krótkoterminowych kar tego typu. Operowano argumentem w postaci braku realnego oddziaływania wychowawczego na ukaranych oraz wskazywano na potencjalne trudności $\mathrm{w}$ organizacji procesu pracy wywołane koniecznością tymczasowego zatrudnienia osób kierowanych celem odbycia kary do uspołecznionych zakładów pracy ${ }^{46}$.

Wszystkie europejskie państwa socjalistyczne wprowadziły szerokie katalogi środków o charakterze ochronnym i profilaktycznym, stanowiące odpowiednik polskich kar dodatkowych. Spośród środków ukierunkowanych przede wszystkim na zapobieganie popełnianiu dalszych wykroczeń wszędzie występowały przepadek przedmiotów służących do popełnienia lub uzyskanych z wykroczenia oraz czasowe pozbawienie uprawnień do wykonywania określonych czynności lub zawodu. Najczęściej ustawodawstwa przewidywały zakaz prowadzenia pojazdów mechanicznych lub innych pojazdów, który w praktyce oznaczał zakaz wykonywania zawodu kierowcy. Powszechnie stosowana była również kara polegająca na podaniu do wiadomości publicznej orzeczenia o ukaraniu ${ }^{47}$. Specyficzny charakter miały występujące $\mathrm{w}$ prawie jugosłowiańskim środki ochronne $\mathrm{w}$ postaci pozbawiania prawa noszenia lub posiadania broni oraz wydalenia cudzoziemca. Podobnie należy ocenić przewidziane $\mathrm{w}$ ZSRR względem osób dopuszczających się pasożytnictwa społecznego zesłanie, czy też wschodnioniemieckie powołanie do pracy $\mathrm{w}$ czasie wolnym od zajęć ${ }^{48}$. Kolejnym oryginalnym rozwiązaniem ustawodawstwa NRD było wpisanie naruszenia obowiązku do akt pracy sprawcy wykroczenia.

Systemy prawa wykroczeń europejskich państw socjalistycznych zakładały szerokie stosowanie wobec sprawców wykroczeń środków oddziaływania wychowawczego. Spośród nich największe znaczenie przypisywano środkom orzekanym samoistnie i z reguły na każde wykroczenie. W niektórych z państw środki te zostały podniesione nawet do rangi kar zasadniczych. Na równi

46 A. Gubiński, Niektóre zagadnienia dotyczace..., s. 8.

47 J. Skupiński, Model polskiego..., s. 190.

48 K. Jandy-Jendrośka, J. Jendrośka, op. cit., s. 447. 
z karą grzywny traktowano naganę (Polska, Bułgaria, Czechosłowacja) oraz upomnienie (Rumunia, Węgry, NRD, ZSRR, Czechosłowacja). Jedynie w Jugosławii kara nagany miała charakter wyjątkowy, gdyż była stosowana zamiast grzywny lub kary pozbawienia wolności ${ }^{49}$. Ponadto, ustawodawstwa Polski, NRD, Węgier, Jugosławii i Bułgarii dopuszczały możliwość odstąpienia od wymierzenia kary i zastosowania $\mathrm{w}$ miejsce represji środków o charakterze wychowawczym lub innych środków nierepresyjnego oddziaływania na sprawcę wykroczenia ${ }^{50}$.

Stopień represyjności prawa wykroczeń poszczególnych europejskich państw socjalistycznych najlepiej oddaje kryterium w postaci występowania kary pozbawienia wolności. Posługując się tym kryterium przedstawione w niniejszym artykule systemy prawne można podzielić na trzy grupy. Najłagodniejsze sankcje groziły sprawcom wykroczeń popełnianych na terenie Czechosłowacji, NRD i Bułgarii i Rumunii. Wynikało to z faktu, iż ustawodawstwo tych państw w ogólne nie operowało karami o charakterze izolacyjnym. Kolejną grupę tworzyły systemy radziecki i węgierski, które traktowały karę pozbawienia wolności za wykroczenie jako środek o charakterze wyjątkowym. W tych krajach areszt był orzekany wobec sprawców nielicznych wykroczeń o dużym ciężarze gatunkowym ujętych $\mathrm{w}$ ustawach szczególnych, aczkolwiek $\mathrm{z}$ racji występowania zastępczej kary aresztu jako bardziej represyjny należy ocenić system węgierski. W skład trzeciej grupy wchodziły Jugosławia i Polska, czyli kraje traktujące areszt jako zwykły środek reakcji na fakt popełnienia wykroczenia. Wobec ustanowienia trzykrotnie wyższej niż w przypadku Jugosławii górnej granicy kary aresztu, polski system prawa wykroczeń należy ocenić jako najbardziej represyjny spośród europejskich państw socjalistycznych. Wprawdzie ustawodawstwo obydwu tych państw podkreślało wyjątkowy charakter kary aresztu, lecz zwłaszcza $\mathrm{w}$ polskim przypadku wprowadzenie tego rodzaju deklaracji miało przede wszystkim wymiar propagandowy. Próbowano za nią ukryć fakt powszechnego posługiwania się tą najsurowszą z kar zasadniczych, gdyż prawie co trzecie wykroczenie uwzględnione w części szczególnej polskiej kodyfikacji zostało obwarowane aresztem i to niemal zawsze w maksymalnym wymiarze ${ }^{51}$.

Represyjność polskiego systemu wzmacniało wprowadzenie innych niż areszt zasadniczy rozwiązań prowadzących do pozbawienia wolności sprawcy wykroczenia. Pozbawienie wolności mogło nastąpić w wyniku zarządzenia wykonania kary aresztu warunkowo zawieszonej, uchylania się ukaranego od wykonania kary ograniczenia wolności oraz zarządzenia wykonania zastępczej kary aresztu na wypadek nieuiszczenia wymierzonej kary grzywny. Sze-

49 J. Skupiński, Ustawodawstwo karno-administracyjne..., s. 89.

50 Idem, Model polskiego..., s. 190.

51 A. Marek, Prawo wykroczeń w zarysie, Warszawa 1975, s. 55. 
rokie posługiwanie się przez kodyfikację z 1971 r. środkami o charakterze izolacyjnym czyniło z polskiego prawa wykroczeń jeden z najbardziej represyjnych systemów nie tylko na tle pozostałych państw socjalistycznych, lecz także w wymiarze ogólnoświatowym ${ }^{52}$.

Formułowaniu tego rodzaju opinii sprzyjał fakt częstego występowania w sankcjach przepisów części szczególnej k.w. kary grzywny w maksymalnym wymiarze. Zbliżony do polskiego górny pułap tej kary występował jedynie na Węgrzech i w Bułgarii, lecz w państwach tych znacznie mniejsza liczba wykroczeń była zagrożona grzywną $\mathrm{w}$ maksymalnym wymiarze. Tkwiącą $\mathrm{w}$ karze grzywny dolegliwość natury majątkowej wzmacniało pominięcie przez twórców k.w. dyrektywy nakazującej uwzględniać przy wymiarze tej kary stosunki majątkowe i dochody sprawcy. Brak tej dyrektywy sprzyjał realizacji fiskalnego kierunku polityki karnej w sprawach o wykroczenia, a zarazem podkreślał wadę kary grzywny, wyrażającą się $\mathrm{w}$ faworyzowaniu bogatych i dyskryminowaniu ubogich ${ }^{53}$.

Polski system prawa wykroczeń należy ocenić jako najbardziej represyjny wśród państw bloku socjalistycznego również z uwagi na występowanie surowych kar dodatkowych. Wprawdzie wszystkie te państwa operowały sankcjami $\mathrm{w}$ postaci pozbawienia prawa wykonywania określonych czynności oraz zakazu prowadzenia pojazdów mechanicznych, lecz w polskich realiach skutki orzeczenia tych kar były szczególnie dotkliwe $\mathrm{z}$ uwagi na najdłuższy okres ich stosowania ${ }^{54}$. Pozbawienie obywatela możliwości wykonywania pracy zarobkowej na okres do roku, a w przypadku kierowców zawodowych nawet na dwa lata stanowiło znacznie surowszy niż grzywna środek represji ekonomicznej.

Nadmierna represyjność cechująca polski system materialnego prawa wykroczeń uległa znacznemu złagodzeniu w wyniku reformy z 1998 r. ${ }^{55}$, której celem było zharmonizowanie części ogólnej k.w. z regulacjami nowego kodeksu karnego ${ }^{56}$. Gruntownej nowelizacji poddano system środków penalnych, obniżając $\mathrm{z}$ trzech do jednego miesiąca górny pułap kary aresztu oraz kary ograniczenia wolności. Wyjątkowy charakter zyskała kara aresztu zastępczego, gdyż obowiązujący k.w. przewiduje w pierwszej kolejności zamianę nieuiszczonej grzywny na pracę społecznie użyteczną. Dyrektywy wymiaru grzywny

52 J. Szumski, Środki karne stosowane wobec sprawców wykroczeń, [w:] Problemy recydywy i drobnej przestępczości w prawie Polski i RFN, red. J. Skupiński, Wrocław 1984, s. 186.

53 D. Pleńska, Wokót problemów nowej kodyfikacji, ZW 1972, nr 2, s. 7.

54 A. Gubiński, Niektóre zagadnienia dotyczace..., s. 8.

55 Przeprowadzona ustawą z dnia 28 sierpnia 1998 r. o zmianie ustawy - Kodeks wykroczeń, ustawy Kodeks postępowania w sprawach o wykroczenia, ustawy o ustroju kolegiów do spraw wykroczeń, ustawy - Kodeks pracy oraz niektórych innych ustaw (Dz. U. Nr 113, poz. 717).

56 Ustawa z dnia 6 czerwca 1997 r. - Kodeks karny (Dz. U. Nr 88, poz. 553). 
uzupełniono o obowiązek uwzględnienia warunków osobistych i rodzinnych sprawcy, jego stosunków majątkowych oraz możliwości zarobkowych ${ }^{57}$.

Krytycznie oceniając typowo represyjny charakter części szczególnej polskiej kodyfikacji, należy podkreślić fakt uwzględniania przez jej twórców socjalistycznej koncepcji wychowawczego oddziaływania na sprawców wykroczeń. Wzorem innych państw socjalistycznych polski system materialnego prawa wykroczeń zawierał stojący $\mathrm{w}$ opozycji względem tradycyjnych kar system środków oddziaływania społeczno-wychowawczego. Przewidywał także możliwość odstąpienia od wymierzania jakiejkolwiek kary ${ }^{58}$. Kodyfikację z 1971 r. należy ocenić jako udane połączenie tradycyjnych koncepcji prawa wykroczeń o charakterze typowo represyjnym, z socjalistyczną ideą oddziaływania wychowawczego.

\section{Bibliografia}

\section{Akty prawne}

Ustawa z dnia 17 czerwca 1966 r. o przekazaniu niektórych drobnych przestępstw jako wykroczeń do orzecznictwa karno-administracyjnego (Dz. U. Nr 23, poz. 149).

Ustawa z dnia 20 maja 1971 r. - Kodeks wykroczeń (Dz. U. Nr 12, poz. 114).

Ustawa z dnia 6 czerwca 1997 r. - Kodeks karny (Dz. U. Nr 88, poz. 553).

Ustawa z dnia 28 sierpnia 1998 r. o zmianie ustawy - Kodeks wykroczeń, ustawy - Kodeks postępowania w sprawach o wykroczenia, ustawy o ustroju kolegiów do spraw wykroczeń, ustawy - Kodeks pracy oraz niektórych innych ustaw (Dz. U. Nr 113, poz. 717).

\section{Projekty aktów prawnych}

Prawo o wykroczeniach. Projekt, Warszawa 1970.

\section{Monografie}

Andrejew I., Ustawowe znamiona czynu. Typizacja i kwalifikacja przestępstw, Warszawa 1978.

Dąbrowski W. F., Zagadnienia ogólne orzecznictwa karno-administracyjnego w PRL, Poznań 1970.

57 M. Łysko, Prace nad kodyfikacją materialnego prawa wykroczeń w Polsce Ludowej (1960-1971), Białystok 2016, s. 322.

58 B. Adamiak, op. cit., s. 122 
Levit P., Sprava a sprawoni prawo. Obecna cast, Praha 1964.

Łysko M., Prace nad kodyfikacja materialnego prawa wykroczeń w Polsce Ludowej (1960-1971), Białystok 2016.

Marek A., Polskie prawo wykroczeń, Warszawa 1987.

Marek A., Prawo wykroczeń w zarysie, Warszawa 1975.

Popovic S., Upravno pravo. Opsti deo, Belgrad 1965.

Skupiński J., Model polskiego prawa o wykroczeniach, Wrocław - Warszawa - Kraków - Gdańsk 1974.

M. Vuckovic, A. Popovic, D. Lisica, Osnovni zakon o prekrsajima sa komentarom i posebnim saveznim proposima o prekrsajima, Belgrad 1967.

\section{Publikacje w pracach zbiorowych}

Cerveny Z., Spravni trestani, [w:] Z. Lukes a kolektiv, Ceskoslovenske spravni pravo, Praha 1981.

Jandy-Jendrośka K., Jendrośka J., Instytucje postępowania w sprawach wykroczeń administracyjnych, [w:] Instytucje prawa administracyjnego europejskich państw socjalistycznych, red. J. Starościak, Warszawa 1973.

Marek A., Problemy reformy polskiego prawa wykroczen, [w:] Problemy odpowiedzialności karnej. Ksiega pamiątkowa ku czci Profesora Kazimierza Buchały, red. Z. Ćwiąkalski, Kraków 1994.

Szumski J., Środki karne stosowane wobec sprawców wykroczeń, [w:] Problemy recydywy i drobnej przestępczości w prawie Polski i RFN, red. J. Skupiński, Wrocław 1984.

\section{Artykuły}

Adamiak B., Ewolucja systemu kar w orzecznictwie w sprawie wykroczeń w PRL, "Acta Universitatis Wratislaviensis. Przegląd Prawa i Administracji" 1976, t. VIII.

Bafia J., Kodyfikacja prawa o wykroczeniach, „Państwo i Prawo” 1971, nr 10.

Bareja Cz., Nowe prawo o wykroczeniach, „Przegląd Pożarniczy” 1971, nr 9.

Buchholz E., Nowe prawo karne NRD, „Przegląd Penitencjarny” 1968, nr 3.

Dąbrowski W. F., Orzecznictwo w sprawach wykroczeń w Czechosłowackiej Republice Socjalistycznej, „Zagadnienia Karno-Administracyjne” 1964, nr 6.

Gubiński A., Niektóre zagadnienia dotyczące ujęcia odpowiedzialności za wykroczenia w europejskich państwach socjalistycznych, „Zagadnienia Wykroczen" 1988, nr 1.

Gubiński A., Radzieckie ustawodawstwo karno-administracyjne, "Zagadnienia Karno-Administracyjne" 1965, nr 1.

Gubiński A., Środki oddziaływania wychowawczego na tle zasady celowości w prawie wykroczeń, „Państwo i Prawo” 1972, nr 10.

Gubiński A., Wokót problemów nowej kodyfikacji, „ZZagadnienia Wykroczeń” 1972, nr 2. 
Haczewski Z., Węgierskie prawo o wykroczeniach, "Gazeta Sądowa i Penitencjarna" 1969 , nr 13.

Hochberg L., Czy Zwiazek Radziecki wprowadzi kodeks wykroczeń?, „Zagadnienia Wykroczeń" 1972, nr 4-5.

Jendrośka J., Rozwój orzecznictwa w sprawach o wykroczenia w Polsce, „Acta Universitatis Wratislaviensis. Przegląd Prawa i Administracji” 1978, t. X.

Łysko M., Prawo wykroczeń Niemieckiej Republiki Demokratycznej, „Miscellanea Historico-Iuridica" 2009, t. VII.

Pleńska D., Wokół problemów nowej kodyfikacji, "Zagadnienia Wykroczeń" 1972, nr 2.

Radecki W., Odpowiedzialność za wykroczenia w systemie środków reakcji na czyny społecznie niebezpieczne, „Prace Naukowe Uniwersytetu Śląskiego. Problemy Prawa Karnego" 1988, nr 14.

Radecki W., System kar i innych środków oddziaływania w prawie wykroczeń, „Służba $\mathrm{MO}^{\prime \prime} 1977$, nr 4-5.

Skupiński J., Bułgarskie prawo wykroczeń, "Zagadnienia Wykroczeń" 1973, nr 6.

Skupiński J., Prawo dotyczące wykroczeń w europejskich państwach socjalistycznych, „Problemy Praworządności" 1973, nr 11.

Skupiński J., Rumuńskie prawo o wykroczeniach, "Zagadnienia Wykroczeń" 1973, nr 2.

Skupiński J., Ustawodawstwo karno-administracyjne w Jugosławii, „Państwo i Prawo” 1970, nr 7.

Skupiński J., Wegierskie ustawodawstwo w sprawach o wykroczenia, „Studia Prawnicze” 1971, z. 30.

Starościak J., Prawo karno-administracyjne w Zwiazku Radzieckim, „Zagadnienia Karno-Administracyjne" 1964, nr 1.

Popowa W. I., Podstawowe problemy ustawodawstwa o odpowiedzialności administracyjnej w ZSRR, "Zagadnienia Karno-Administracyjne” 1966, nr 3-4.

\section{Inne pozycje}

Ordnungswidrigkeitrecht der DDR. Kommentar zum Ordnungswidrigkeitsgesetz und zur Ordnungswidirgkeitsverordnung, Berlin 1989.

Skupiński J., Prawo o wykroczeniach w europejskich państwach socjalistycznych, t. 1, Ludowa Republika Bułgarii, Węgierska Republika Ludowa, Wrocław - Warszawa - Kraków - Gdańsk 1975.

Skupiński J., Prawo o wykroczeniach w europejskich państwach socjalistycznych, t. 2, Niemiecka Republika Demokratyczna, Wrocław - Warszawa - Kraków - Gdańsk 1974. 